\title{
Li4Ca3Si2N6 and Li4Sr3Si2N6 - Quaternary Lithium Nitridosilicates with Isolated [Si2N6]10- Ions
}

\begin{tabular}{|r|l|}
\hline Journal: & Zeitschrift für Anorganische und Allgemeine Chemie \\
\hline Manuscript ID: & zaac.201000163.R1 \\
\hline Wiley - Manuscript type: & Communication \\
\hline Date Submitted by the \\
Author: & 19-May-2010 \\
\hline Complete List of Authors: & $\begin{array}{l}\text { Pagano, Sandro; LMU Munich, Chemistry } \\
\text { Lupart, Saskia; LMU Munich, Chemistry } \\
\text { Schmiechen, Sebastian; LMU Munich, Chemistry } \\
\text { Schnick, Wolfgang; LMU Munich, Chemistry }\end{array}$ \\
\hline Keywords: & Lithium, Fluxing agent, Strontium, Nitridosilicate, X-ray diffraction \\
\hline \multicolumn{2}{|l}{} \\
\hline
\end{tabular}

\section{S ScholaroNE" \\ Manuscript Central}




\title{
$\mathrm{Li}_{4} \mathrm{Ca}_{3} \mathrm{Si}_{2} \mathrm{~N}_{6}$ and $\mathrm{Li}_{4} \mathrm{Sr}_{3} \mathrm{Si}_{2} \mathrm{~N}_{6}$ - Quaternary Lithium Nitridosilicates with Isolated $\left[\mathrm{Si}_{2} \mathrm{~N}_{6}\right]^{10-}$ Ions
}

\author{
Sandro Pagano, ${ }^{[\mathrm{a}]}$ Saskia Lupart, ${ }^{[\mathrm{a}]}$ Sebastian Schmiechen, ${ }^{[\mathrm{a}]}$ and Wolfgang Schnick ${ }^{[\mathrm{a}]^{*}}$ \\ Department Chemie der Ludwig-Maximilians-Universität München
}

Prof. Dr. W. Schnick

Department Chemie

Lehrstuhl für Anorganische Festkörperchemie

Ludwig-Maximilians-Universität München

Butenandtstraße 5 - 13 (D)

D-81377 München, Germany

Fax: +49-(0)89-2180-77440

E-mail: wolfgang.schnick@uni-muenchen.de 


\begin{abstract}
The isotypic nitridosilicates $\mathrm{Li}_{4} \mathrm{Ca}_{3} \mathrm{Si}_{2} \mathrm{~N}_{6}$ and $\mathrm{Li}_{4} \mathrm{Sr}_{3} \mathrm{Si}_{2} \mathrm{~N}_{6}$ were synthesized by reaction of $\mathrm{Sr}$ or $\mathrm{Ca}$ with $\mathrm{Si}(\mathrm{NH})_{2}$ and additional excess of $\mathrm{Li}_{3} \mathrm{~N}$ in weld shut tantalum ampoules. The crystal structure, which has been solved by single-crystal X-ray diffraction $\left(\mathrm{Li}_{4} \mathrm{Sr}_{3} \mathrm{Si}_{2} \mathrm{~N}_{6}: C 2 / m, Z=2\right.$, $\left.a=6.1268(12), b=9.6866(19), c=6.2200(12) \AA, \beta=90.24(3)^{\circ}, w R 2=0.0903\right)$ is made up from isolated $\left[\mathrm{Si}_{2} \mathrm{~N}_{6}\right]^{10-}$ ions and is isotypic to $\mathrm{Li}_{4} \mathrm{Sr}_{3} \mathrm{Ge}_{2} \mathrm{~N}_{6}$. The bonding angels and distances within the edge-sharing $\left[\mathrm{Si}_{2} \mathrm{~N}_{6}\right]^{10-}$ double-tetrahedra are strongly dependent on the lewis acidity of the counter ions. This finding is discussed in relation to the compounds $\mathrm{Ca}_{5} \mathrm{Si}_{2} \mathrm{~N}_{6}$ and $\mathrm{Ba}_{5} \mathrm{Si}_{2} \mathrm{~N}_{6}$ which also exhibit isolated $\left[\mathrm{Si}_{2} \mathrm{~N}_{6}\right]^{10-}$ ions.
\end{abstract}

\title{
Keywords
}

Lithium; Fluxing Agent; Strontium; Nitridosilicates; X-Ray diffraction

\section{Introduction}

Recently, we have reported on the utilization of liquid lithium for the synthesis of quaternary lithium nitridosilicates. The ability of liquid lithium to dissolve a variety of metals, silicon and nitrogen allows for a controlled synthesis of group-type silicates, chain-like anions up to frameworks by simply adjusting the $\mathrm{Li}_{3} \mathrm{~N}$ content, the nitrogen pressure $\left(\mathrm{LiN}_{3}\right)$ and the reaction temperature. ${ }^{[1]}$ By adding an excess of $\mathrm{Li}_{3} \mathrm{~N}$ to the reaction mixture higher condensation of the $\left[\mathrm{SiN}_{4}\right]$-tetrahedra network is suppressed and the lowest degree of condensation for nitridosilicates is observed. Orthosilicate-like isolated $\left[\mathrm{SiN}_{4}\right]^{8-}$ tetrahedra, which might occur in the compound $\mathrm{Li}_{8} \mathrm{SiN}_{4}$ are not yet structurally verified. ${ }^{[2,3]}$ Consequently, up to now group-type silicates made up from edge-sharing $\left[\mathrm{Si}_{2} \mathrm{~N}_{6}\right]^{10-}$ doubletetrahedra represent nitridosilicates with the lowest degree of condensation characterized by single-crystal X-ray diffractometry so far. Identical building blocks have already been reported for $\mathrm{Ba}_{5} \mathrm{Si}_{2} \mathrm{~N}_{6}$ synthesized by DiSalvo et al. in a sodium flux and $\mathrm{Ca}_{5} \mathrm{Si}_{2} \mathrm{~N}_{6}$ obtained via solid-state reaction of $\mathrm{Ca}_{2} \mathrm{~N}$ and $\mathrm{Si}^{[4,5]}$ In this contribution we report on synthesis and structural features of $\mathrm{Li}_{4} \mathrm{Ca}_{3} \mathrm{Si}_{2} \mathrm{~N}_{6}$ and on the isotypic $\mathrm{Sr}$-phase.

\section{Results and discussion}


$\mathrm{Li}_{4} \mathrm{Ca}_{3} \mathrm{Si}_{2} \mathrm{~N}_{6}$ and $\mathrm{Li}_{4} \mathrm{Sr}_{3} \mathrm{Si}_{2} \mathrm{~N}_{6}$ were synthesized from the corresponding metals, $\mathrm{Si}(\mathrm{NH})_{2}$ and an excess of $\mathrm{Li}_{3} \mathrm{~N}$ in weld shut tantalum ampoules at $900{ }^{\circ} \mathrm{C}$. Addition of $\mathrm{Li}$ metal as a fluxing agent was not essential for the synthesis of suitable single crystals. This might be due to $\mathrm{Li}_{3} \mathrm{~N}$ acting as a flux as it melts above $815^{\circ} \mathrm{C}$ under autogenous nitrogen pressure in closed systems. ${ }^{[6]}$ The title compounds are not stable against air and moisture and were handled under inert gas atmosphere. The approximate atomic ratio of heavy elements $(\mathrm{Ca} / \mathrm{Sr}$ and $\mathrm{Si})$ was determined by energy dispersive $X$-ray microanalysis. $\mathrm{Li}_{4} \mathrm{Ca}_{3} \mathrm{Si}_{2} \mathrm{~N}_{6}$ and $\mathrm{Li}_{4} \mathrm{Sr}_{3} \mathrm{Si}_{2} \mathrm{~N}_{6}$ crystallize in the monoclinic space group $C 2 / m$ with two formula units per unit cell (for details see Table 1).

The unit cell and coordination spheres of $\mathrm{Li}_{4} \mathrm{Sr}_{3} \mathrm{Si}_{2} \mathrm{~N}_{6}$ are depicted in Figure 1 and Figure 2, respectively. The asymmetric unit consist of two $\mathrm{Sr}$ and $\mathrm{N}$ sites, one $\mathrm{Si}$ and $\mathrm{Li}$ site named according to Figure 2. The structure is built up from isolated $\left[\mathrm{Si}_{2} \mathrm{~N}_{6}\right]^{10-}$ ions and is isotypic to that of the nitridogermanate $\mathrm{Li}_{4} \mathrm{Sr}_{3} \mathrm{Ge}_{2} \mathrm{~N}_{6} .{ }^{[7]}$ Group-like $\left[\mathrm{Si}_{2} \mathrm{~N}_{6}\right]^{10-}$ ions have already been reported for $\mathrm{Ca}_{5} \mathrm{Si}_{2} \mathrm{~N}_{6}$ and $\mathrm{Ba}_{5} \mathrm{Si}_{2} \mathrm{~N}_{6} \cdot{ }^{[4,5]}$ Due to the edge-sharing of [ $\left.\mathrm{SiN}_{4}\right]$ tetrahedra, the tetrahedra angels are distorted to values of $91-96^{\circ}$ (N2-Si1-N2) for all compounds (cf. Table 2). The corresponding Si1-N2 bonds are elongated from $1.74 \AA$ to $1.81-1.85 \AA$, resulting in quite short $\mathrm{Si1}-\mathrm{Si1}$ distances ranging from $2.40(1) \AA$ in $\mathrm{Ca}_{5} \mathrm{Si}_{2} \mathrm{~N}_{6}$ to $2.556(7) \AA$ in $\mathrm{Ba}_{5} \mathrm{Si}_{2} \mathrm{~N}_{6}{ }^{[4,5]}$ The Si1-Sil distances of $\mathrm{Li}_{4} \mathrm{Ca}_{3} \mathrm{Si}_{2} \mathrm{~N}_{6}$ and $\mathrm{Li}_{4} \mathrm{Sr}_{3} \mathrm{Si}_{2} \mathrm{~N}_{6}$ are ranging in between these values (cf. Table 2). Regarding the series of isolated $\left[\mathrm{Si}_{2} \mathrm{~N}_{6}\right]^{10-}$ ions one could assume that the distortion of the square built up from Si1 and N2 is dependent on the lewis acidity of the surrounding metal ions. The smaller ionic radius of $\mathrm{Ca}^{2+}$ compared to $\mathrm{Sr}^{2+}$ and $\mathrm{Ba}^{2+}$ leads to shorter N-metal distances and the higher lewis acidity results in a displacement of N2 from the ideal square built up from Si1 and N2. Consequently, the angels Si-N2-Si are increasing from 91.1(1) ${ }^{\circ}$ in $\mathrm{Ba}_{5} \mathrm{Si}_{2} \mathrm{~N}_{6}, 93.2(3)^{\circ}$ in $\mathrm{Li}_{4} \mathrm{Sr}_{3} \mathrm{Si}_{2} \mathrm{~N}_{6}$ to $96.7(1)^{\circ}$ in $\mathrm{Ca}_{5} \mathrm{Si}_{2} \mathrm{~N}_{6} \cdot{ }^{[4,5]}$ Presumably, this effect is responsible for the decrease of the distances $\mathrm{Si1}-\mathrm{Si} 1$ in the sequence $\mathrm{Ba}^{2+}, \mathrm{Sr}^{2+}$ to $\mathrm{Ca}^{2+}$ (Table 2). The distances N-EA (EA = alkaline earth) in $\mathrm{Li}_{4} \mathrm{Ca}_{3} \mathrm{Si}_{2} \mathrm{~N}_{6}$ and $\mathrm{Li}_{4} \mathrm{Sr}_{3} \mathrm{Si}_{2} \mathrm{~N}_{6}$ are in the typical range for alkaline earth nitrides. ${ }^{[8]}$ In $\mathrm{Li}_{4} \mathrm{Ca}_{3} \mathrm{Si}_{2} \mathrm{~N}_{6}$ both metal sites are coordinated by six $\mathrm{N}$-atoms, whereas in $\mathrm{Li}_{4} \mathrm{Sr}_{3} \mathrm{Si}_{2} \mathrm{~N}_{6} \mathrm{Sr} 1$ exhibits a $6+2$ coordination. The coordination spheres (cf. Figure 2) were assigned by lattice energy calculations (MAPLE; Madelung part of lattice energie). ${ }^{[9,10]}$ In both compounds Li1 is coordinated by four N-atoms in distorted tetrahedral fashion $\left(105-123^{\circ}\right)$ with typical distances $\mathrm{Li}-\mathrm{N}$ (values within the sum of the ionic radii). ${ }^{[9,11]}$ The smaller lattice parameters of $\mathrm{Li}_{4} \mathrm{Ca}_{3} \mathrm{Si}_{2} \mathrm{~N}_{6}$ also lead to significantly shorter Li-N distances (Li1-N1: 1.968(3), 2.072(3), 2.123(3) ̊, Li1-N2: 2.259(3) ̊̊). Edgesharing of $\left[\mathrm{LiN}_{4}\right]$-polyhedra along [100] causes chains of $\mathrm{Li}^{+}$-ions with quite short Li1-Li1 
distances $\left(\mathrm{Li}_{4} \mathrm{Ca}_{3} \mathrm{Si}_{2} \mathrm{~N}_{6}: 2.213(6), 2.447(6) \AA \mathrm{Ai}_{4} \mathrm{Sr}_{3} \mathrm{Si}_{2} \mathrm{~N}_{6}: 2.273(18), 2.487(19) \AA\right)$. The Li-ion conductor $\mathrm{Li}_{2} \mathrm{SiN}_{2}$ exhibits comparable chains of $\left[\mathrm{LiN}_{\mathrm{x}}\right]$-polyhedra with analogoues $\mathrm{Li}-\mathrm{Li}$ distances. ${ }^{[12]}$ It may be noted that the addition of $1 \%$ of Eu to the reaction mixture yielded red single crystals, which, however showed no fluorescence under UV light at room temperature.

\section{Conclusion}

In this contribution, we demonstrate that addition of an excess of $\mathrm{Li}_{3} \mathrm{~N}$ to the reaction mixture of $\mathrm{Ca} / \mathrm{Sr}$ and $\mathrm{Si}(\mathrm{NH})_{2}$ suppresses the higher condensation of $\left[\mathrm{SiN}_{4}\right]$-tetrahedra and a low degree of condensation for nitridosilicates is achieved. The isotypic compounds $\mathrm{Li}_{4} \mathrm{Ca}_{3} \mathrm{Si}_{2} \mathrm{~N}_{6}$ and $\mathrm{Li}_{4} \mathrm{Sr}_{3} \mathrm{Si}_{2} \mathrm{~N}_{6}$ are the third and fourth example of nitridosilicates containing isolated $\left[\mathrm{Si}_{2} \mathrm{~N}_{6}\right]^{10-}$ ions, respectively. Presumably, the lengths of the distances Si-Si within the $\left[\mathrm{Si}_{2} \mathrm{~N}_{6}\right]^{10-}$ ions is dependent on the lewis acidity of the counter ions. It may be noted that the presence of [ $\left.\mathrm{LiN}_{4}\right]$-polyhedra chains along [100] might be an interesting feature for lithium ion conductivity.

\section{Experimental Section}

All manipulations were performed with rigorous exclusion of oxygen and moisture in flamedried Schlenk-type glassware on a Schlenk line interfaced to a vacuum $\left(10^{-3} \mathrm{mbar}\right)$ line or in an argon-filled glove box (Unilab, MBraun, Garching, $\mathrm{O}_{2}<0.1 \mathrm{ppm}, \mathrm{H}_{2} \mathrm{O}<0.1 \mathrm{ppm}$ ). $\mathrm{Li}_{3} \mathrm{~N}$ was purchased from Alfa Aesar (99.4\%), Ca and Sr from Sigma-Aldrich (99.99\%) and $\mathrm{Si}(\mathrm{NH})_{2}$ was synthesized according to the literature. ${ }^{[13]}$

For the reactions, tantalum crucibles (wall thickness $0.5 \mathrm{~mm}$, internal diameter $10 \mathrm{~mm}$, length $300 \mathrm{~mm}$ ) were cleaned in a mixture of $\mathrm{HNO}_{3}$ (conc.) and $\mathrm{HF}(40 \%)$. They were arc-welded under a pressure of 1 bar purified argon. The crucible holder was water cooled in order to avoid decomposition reactions during welding.

Single crystals of $\mathrm{Li}_{4} \mathrm{Ca}_{3} \mathrm{Si}_{2} \mathrm{~N}_{6}$ and $\mathrm{Li}_{4} \mathrm{Sr}_{3} \mathrm{Si}_{2} \mathrm{~N}_{6}$ were synthesized from $60 \mathrm{mg} \mathrm{Li}_{3} \mathrm{~N}$ (1.72 mmol), $50 \mathrm{mg} \mathrm{Si}(\mathrm{NH})_{2}(0.86 \mathrm{mmol})$ and $34 \mathrm{mg} \mathrm{Ca}(0.86 \mathrm{mmol}) / 75 \mathrm{mg} \mathrm{Sr}(0.86 \mathrm{mmol})$ in closed tantalum crucibles placed in silica tubes. The silica tube (under argon) was placed in the middle of a tube furnace. The temperature was raised to $900{ }^{\circ} \mathrm{C}$ (rate $180{ }^{\circ} \mathrm{Ch}^{-1}$ ), maintained for $48 \mathrm{~h}$, subsequently cooled to $500{ }^{\circ} \mathrm{C}$ (rate $5^{\circ} \mathrm{C} \mathrm{h}^{-1}$ ) and finally quenched to room temperature by switching off the furnace. 
$X$-ray diffraction: By inspection under a microscope integrated in a glove box, colorless single crystals of the title compounds were isolated from residual $\mathrm{Li}_{3} \mathrm{~N}$ and enclosed in glass capillaries. Single-crystal X-ray diffraction data were collected on a Stoe IPDS I for $\mathrm{Li}_{4} \mathrm{Ca}_{3} \mathrm{Si}_{2} \mathrm{~N}_{6}$ and on an Oxford Diffraction XCalibur for $\mathrm{Li}_{4} \mathrm{Sr}_{3} \mathrm{Si}_{2} \mathrm{~N}_{6}$ (Mo $\mathrm{Mo}_{\mathrm{K} a}$ radiation). The program package SHELX97 was used for structure solution and refinement. ${ }^{[14]}$ Further details of the crystal structure investigations can be obtained from the Fachinformationszentrum Karlsruhe, 76344 Eggenstein-Leopoldshafen, Germany (fax: (+49)7247-808-666; e-mail: crysdata@ fiz-karlsruhe.de) on quoting the depository number CSD-420675 $\left(\mathrm{Li}_{4} \mathrm{Ca}_{3} \mathrm{Si}_{2} \mathrm{~N}_{6}\right)$ and CSD-421259 $\left(\mathrm{Li}_{4} \mathrm{Sr}_{3} \mathrm{Si}_{2} \mathrm{~N}_{6}\right)$, the names of the authors and citation of the publication.

Microanalysis: EDX spectra of selected crystals were obtained using a JSM 6500F scanning electron microscope (JEOL) equipped with an EDX detector 7418 (Oxford Instruments). The approximate molar ratio of the elements $\mathrm{Ca}: \mathrm{Si}$ was found to be 22(2) : 14(2) (average from 3 independent measurements) for $\mathrm{Li}_{4} \mathrm{Ca}_{3} \mathrm{Si}_{2} \mathrm{~N}_{6}$ and $\mathrm{Sr}: \mathrm{Si}$ was found to be 19(2):13(2) (average from 3 independent measurements) for $\mathrm{Li}_{4} \mathrm{Sr}_{3} \mathrm{Si}_{2} \mathrm{~N}_{6}$.

\section{Acknowledgments}

We thank Dr. Peter Mayer, Thomas Miller (single-crystal X-ray diffractometry) and Christian Minke (X-ray microanalysis). The authors gratefully acknowledge financial support from the Fonds der Chemischen Industrie (FCI) and the Deutsche Forschungsgemeinschaft (DFG), project SCHN 377/ 14-1. 
Table 1. Crystallographic data of $\mathrm{Li}_{4} \mathrm{Ca}_{3} \mathrm{Si}_{2} \mathrm{~N}_{6}$ and $\mathrm{Li}_{4} \mathrm{Sr}_{3} \mathrm{Si}_{2} \mathrm{~N}_{6}$.

\begin{tabular}{|c|c|c|}
\hline Formula & $\mathrm{Li}_{4} \mathrm{Ca}_{3} \mathrm{Si}_{2} \mathrm{~N}_{6}$ & $\mathrm{Li}_{4} \mathrm{Sr}_{3} \mathrm{Si}_{2} \mathrm{~N}_{6}$ \\
\hline Formula mass $/ \mathrm{g} \cdot \mathrm{mol}^{-1}$ & 288.24 & 430.86 \\
\hline Crystal system & \multicolumn{2}{|c|}{ monoclinic } \\
\hline Space group & \multicolumn{2}{|c|}{$C 2 / m($ no. 12$)$} \\
\hline \multirow{4}{*}{ Cell parameters / $\AA{ }^{\circ}{ }^{\circ}$} & $a=5.7873(12)$ & $a=6.1268(12)$ \\
\hline & $b=9.7045(19)$ & $b=9.6866(19)$ \\
\hline & $c=5.9771(12)$ & $c=6.2200(12)$ \\
\hline & $\beta=90.45(3)$ & $\beta=90.24(3)$ \\
\hline Cell volume $/ 10^{6} \mathrm{pm}^{3}$ & $V=335.68(12)$ & $V=369.14(12)$ \\
\hline Formula units / cell & \multicolumn{2}{|r|}{2} \\
\hline Crystal size $/ \mathrm{mm}^{3}$ & $0.08 \cdot 0.05 \cdot 0.02$ & $0.14 \cdot 0.12 \cdot 0.05$ \\
\hline$\rho_{\text {calcd. }} / \mathrm{g} \cdot \mathrm{cm}^{-3}$ & 2.852 & 3.876 \\
\hline$\mu / \mathrm{mm}^{-1}$ & 2.751 & 21.86 \\
\hline$F(000)$ & 284 & 392 \\
\hline Diffractometer & Stoe IPDS I & $\begin{array}{c}\text { Oxford } \\
\text { Diffraction } \\
\text { XCalibur }\end{array}$ \\
\hline Temperature / K & $295(2)$ & $200(2)$ \\
\hline $\begin{array}{l}\text { Radiation, } \\
\text { monochromator }\end{array}$ & \multicolumn{2}{|c|}{ Mo-K ${ }_{\alpha},(\lambda=71.073 \mathrm{pm})$, graphite } \\
\hline Absorption correction & multi-scan & numerical \\
\hline min. /max. transmission & $0.726 / 0.946$ & $0.0467 / 0.466$ \\
\hline$\theta$ range $/^{\circ}$ & $2.3-30.5$ & $3.89-29.99$ \\
\hline Measured reflections & 1787 & 1221 \\
\hline Independent reflections & 505 & 539 \\
\hline Observed reflections & 450 & 456 \\
\hline Refined parameters & 36 & 36 \\
\hline GoF & 1.117 & 1.122 \\
\hline$R$ indices $\left(\mathrm{F}_{\mathrm{o}}^{2} \geq 2 \sigma\left(\mathrm{F}_{\mathrm{o}}^{2}\right)\right)$ & $\begin{array}{l}R 1=0.0219 \\
w R 2=0.0566\end{array}$ & $\begin{array}{l}R 1=0.0314 \\
w R 2=0.0903\end{array}$ \\
\hline$R$ indices (all data) & $\begin{array}{l}R 1=0.0252 \\
w R 2=0.0572^{[\mathrm{a}]}\end{array}$ & $\begin{array}{l}R 1=0.0370 \\
w R 2=0.0935^{[\mathrm{b}]}\end{array}$ \\
\hline $\begin{array}{l}\text { Max. / min. residual } \\
\text { electron density/ e } \AA^{-3}\end{array}$ & $0.512 /-0.457$ & $1.816 /-1.741$ \\
\hline
\end{tabular}


Table 2. Comparison of compounds exhibiting isolated $\left[\mathrm{Si}_{2} \mathrm{~N}_{6}\right]^{10-}$ ions.

\begin{tabular}{lcccc}
\hline & & \multicolumn{2}{c}{$\mathrm{Li}_{4} \mathrm{M}_{3} \mathrm{Si}_{2} \mathrm{~N}_{6}$} \\
& $\mathrm{Ba}_{5} \mathrm{Si}_{2} \mathrm{~N}_{6}{ }^{[5]}$ & $\mathrm{Ca}_{5} \mathrm{Si}_{2} \mathrm{~N}_{6}{ }^{[4]}$ & $\mathrm{Ca}$ & $\mathrm{Sr}$ \\
\hline Synthesis & $\mathrm{Na}-\mathrm{Flux}$ & solid-state & $\mathrm{Li}-\mathrm{Flux}$ & $\mathrm{Li}-\mathrm{Flux}$ \\
Space group & $P 2_{1} 2_{1} 2_{1}$ & $C 2 / c$ & $C 2 / m$ & $C 2 / m$ \\
$\mathrm{X}-$-ray T $/ \mathrm{K}$ & 293 & 293 & 293 & 200 \\
$\mathrm{Si}-\mathrm{Si} / \AA$ & $2.556(7)$ & $2.40(1)$ & $2.453(1)$ & $2.540(4)$ \\
$\mathrm{Si}-\mathrm{N} 2 / \AA$ & $1.83(2)^{[\mathrm{a}]}$ & $1.81(1)^{[\mathrm{a}]}$ & $1.83(1)^{[\mathrm{a}]}$ & $1.85(1)^{[\mathrm{a}]}$ \\
$\mathrm{Si}-\mathrm{N} 1 / \AA$ & $91.1(1)^{[\mathrm{a}]}$ & $96.7(1)^{[\mathrm{a}]}$ & $95.9(1)$ & $93.2(3)$ \\
$\mathrm{Si}-\mathrm{N} 2-\mathrm{Si} /{ }^{\circ}$ & $1.75(2)^{[\mathrm{a}]}$ & $1.73(1)^{[\mathrm{a}]}$ & $1.711(2)$ & $1.735(4)$ \\
\hline \multicolumn{5}{l}{ [a] Averaged values because of more than one set of symmetry } \\
independent bonds/angles.
\end{tabular}


Figure 1. Two unit cells of $\mathrm{Li}_{4} \mathrm{Sr}_{3} \mathrm{Si}_{2} \mathrm{~N}_{6}$ along [00-1]. Ellipsoids at $90 \%$ probability level. $\left[\mathrm{SiN}_{4}\right]$ units are depicted as closed gray tetrahedra, $\mathrm{N}$ atoms black, $\mathrm{Sr}$ ions white/black and $\mathrm{Li}$ ions gray.

Figure 2. Coordination spheres in $\mathrm{Li}_{4} \mathrm{Sr}_{3} \mathrm{Si}_{2} \mathrm{~N}_{6}$. N atoms black, $\mathrm{Sr}$ ions white and Li ions gray. 


\section{References}

[1] S. Pagano, S. Lupart, M. Zeuner, W. Schnick, Angew. Chem. 2009, 121, 6453-6456; Angew. Chem., Int. Ed. 2009, 48, 6335-6338.

[2] J. Lang, J.-P. Charlot, Rev. Chim. Miner. 1970, 7, 121-131.

[3] H. Yamane, S. Kikkawa, M. Koizumi, Solid State Ionics 1987, 25, 183-191.

[4] F. Ottinger, R. Nesper, Z. Anorg. Allg. Chem. 2005, 631, 1597-1602.

[5] H. Yamane, F. J. DiSalvo, J. Alloys Compd. 1996, 240, 33-36.

[6] R. P. Elliot, Constitution of Binary Alloys, McGraw-Hill Book Company, New York, 1965.

[7] D. G. Park, Z. A. Gál, F. J. DiSalvo, J. Solid State Chem. 2003, 172, 166-170.

[8] P. Hoehn, S. Hoffmann, J. Hunger, S. Leoni, F. Nitsche, W. Schnelle, R. Kniep, Chem. Eur. J. 2009, 15, 3419-3425.

[9] R. D. Shannon, Acta Crystallogr., Sect. A: Cryst. Found. Crystallogr. 1976, 32, 751-767.

[10] R. Hübbenthal, Programm zur Berechnung des Madelunganteils der Gitterenergie, Vers. 4; Universität Gießen 1993.

[11] H. Baur, Crystallogr. Rev. 1987, 1, 59-83.

[12] S. Pagano, M. Zeuner, S. Hug, W. Schnick, Eur. J. Inorg. Chem. 2009, 1579-1584.

[13] H. Lange, G. Wötting, G. Winter, Angew. Chem. 1991, 103, 1606-1625; Angew. Chem., Int. Ed. Engl. 1991, 30, 1579-1597.

[14] G. M. Sheldrick, Acta Crystallogr., Sect. A: Found. Crystallogr. 2008, 64, 112-122. 


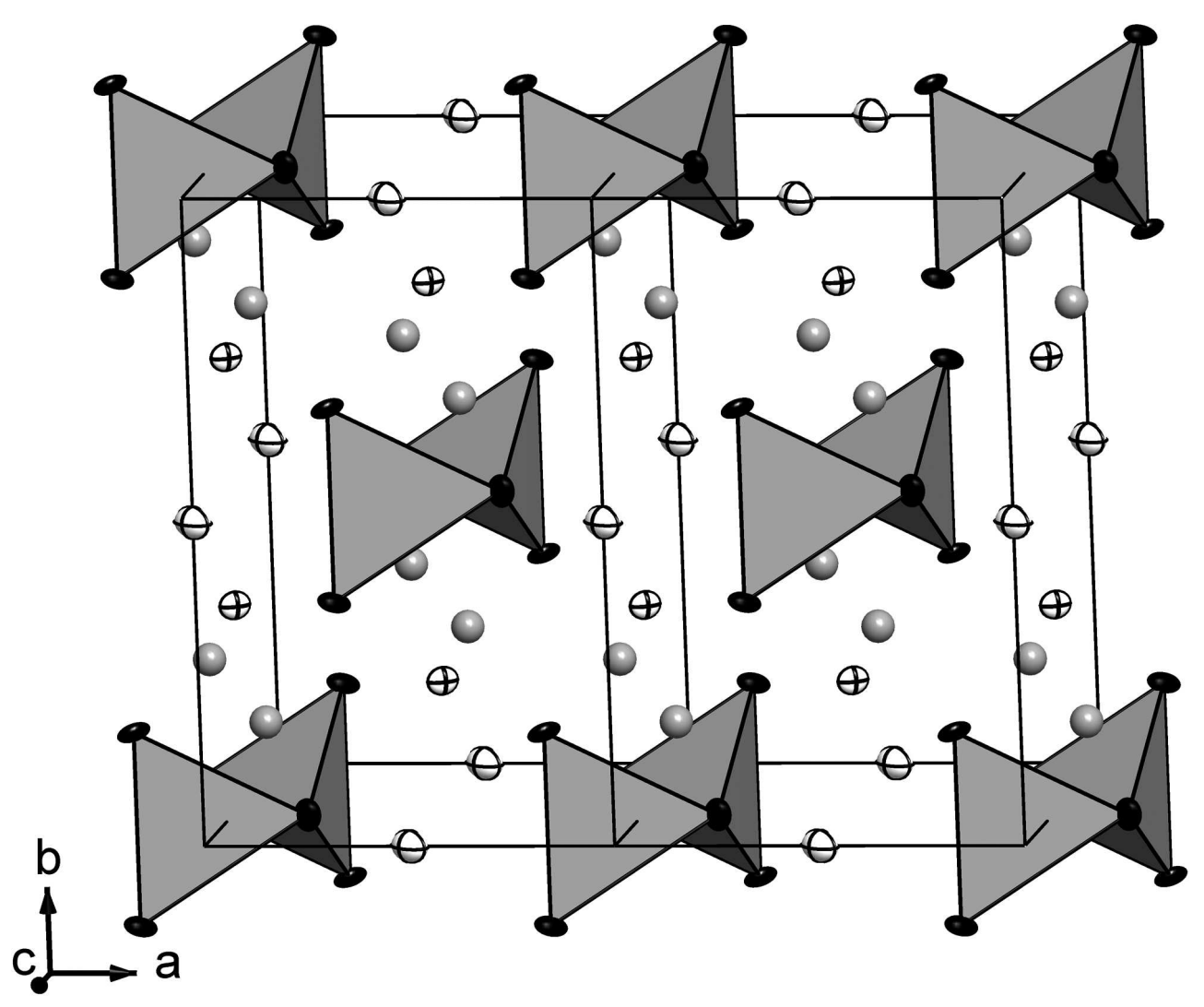

Figure1

$85 \times 70 \mathrm{~mm}(600 \times 600$ DPI $)$ 

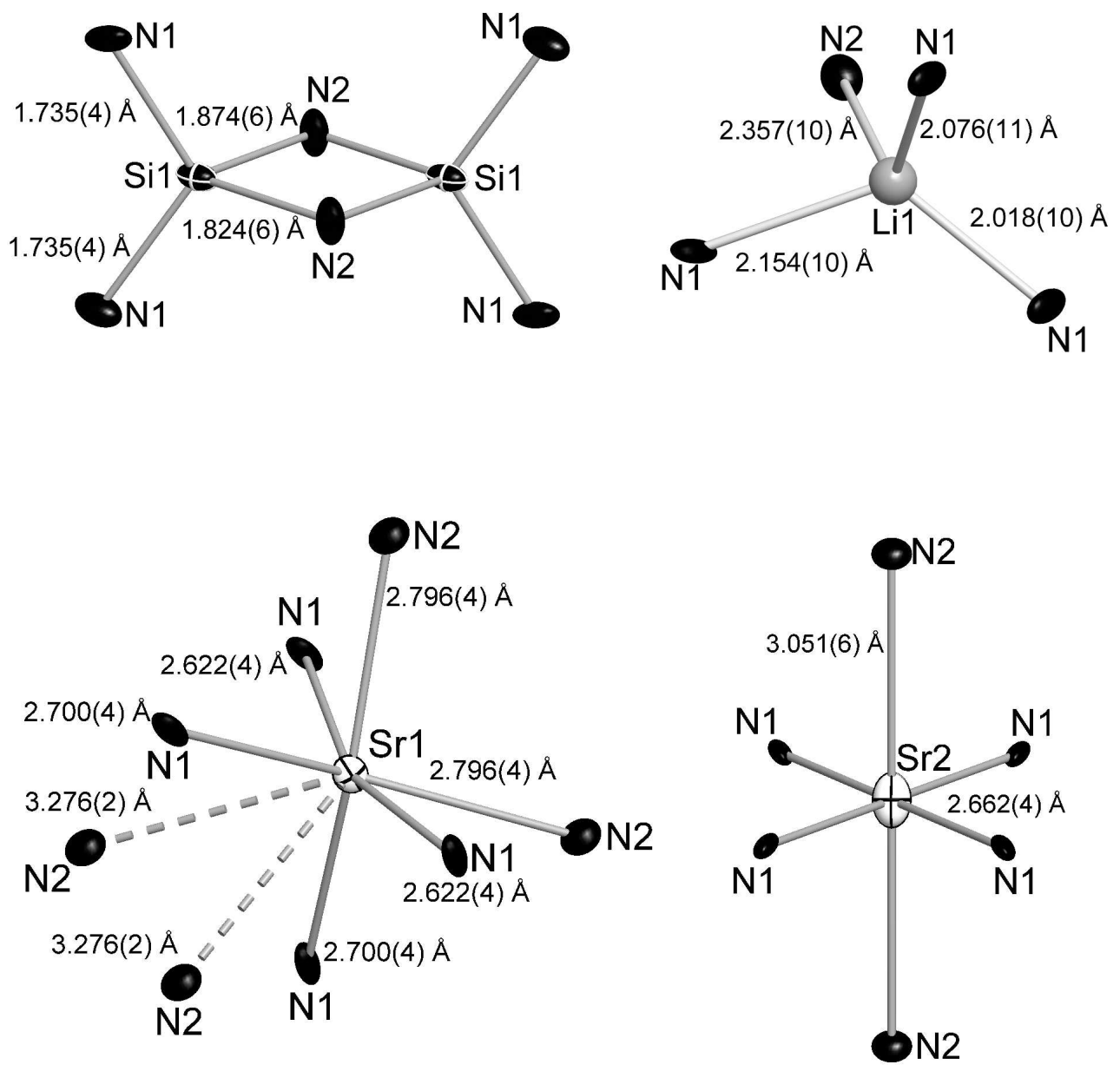

Figure2 